Archives of Agriculture and Environmental Science

\title{
Effect of age of seedlings on the performance of drought tolerant Aman rice cultivars
}

\author{
Shakil Hosain ${ }^{1}$ (D) , Sarmin Akter ${ }^{1}$, Narayan Chakraborty ${ }^{1}$, Safayet Hossen ${ }^{1}$, Kawsar Hossen ${ }^{1^{*}}$ \\ and Md. Golam Rabbani ${ }^{2}$
}

${ }^{1}$ Department of Agriculture, Noakhali Science and Technology University, Noakhali-3814, BANGLADESH

${ }^{2}$ Research Officer, Research Cell, Noakhali Science and Technology University, Noakhali-3814, BANGLADESH

"Corresponding author's Email: kwsarbau@gmail.com

\section{ARTICLE HISTORY}

Received: 13 November 2018

Revised received: 30 November 2018

Accepted: 02 December 2018

\section{ABSTRACT}

An experiment was conducted at the Field Laboratory of the Department of Agriculture, Noakhali Science and Technology University (NSTU), Sonapur, Noakhali, from July 2017 to December 2017 to study the effect of variety and age of seedling on yield performance of drought tolerant transplant aman rice. The experiment consisted of three varieties viz. BINA dhan7, BRRI dhan56 and BRRI dhan71 and five different ages of seedling viz.15 days old, 20 days old, 25 days old, 30 days old, and 35 days old. The experimental design was randomized complete block design (RCBD) with three replications. Among the three varieties, BRRI dhan71 produced the highest grain yield $\left(5.567 \mathrm{t} \mathrm{ha}^{-1}\right)$ and the lowest grain yield $\left(4.975 \mathrm{tha}^{-1}\right)$ was obtained from BRRI dhan56. Among the five ages of seedlings, the highest grain yield ( $5.502 \mathrm{t} \mathrm{ha}^{-1}$ ) was obtained from 35 days old seedling and the lowest grain yield (5.092 $\mathrm{t} \mathrm{ha}^{-1}$ ) was obtained from 15 days old seedling. In case of interaction between variety and spacing, the highest grain yield $\left(5.723 \mathrm{t} \mathrm{ha}^{-1}\right)$ was obtained from BRRI dhan71 with 35 days old seedling and the lowest ( $4.730 \mathrm{t} \mathrm{ha}^{-1}$ ) was obtained from BRRI dhan 56 with 15 days old seedling. The result reveals that relatively older seedlings (35-days old) produce higher grain yield compared to the younger ones.

(C)2018 Agriculture and Environmental Science Academy

Citation of this article: Hosain, S., Akter, S., Chakraborty, N., Hossen, S., Hossen, K. and Rabbani, M.D. (2018). Effect of age of seedlings on the performance of drought tolerant Aman rice cultivars. Archives of Agriculture and Environmental Science, 3(4): 388-393, https://dx.doi.org/10.26832/24566632.2018.0304010

\section{INTRODUCTION}

Bangladesh is an agro based country and most of the economic activities of this country depend on agriculture. Agriculture in Bangladesh is dominated by rice cultivation. Rice (Oryza sativa L.) is the major cereal crop and staple food of Bangladesh. It is the extensively cultivated crop for half of the world's population (FAO, 2010). On the basis of volume of production, Aman rice is the second largest rice crop in the country while Boro rice holds the first position. In the Financial Year 2015-16, the total Aman rice production has been estimated $1,34,83,437$ metric tons which is $2.22 \%$ higher than that of the previous year and it covers 55,90,340 hectares of land area. In 2014-15, the total Aman rice production was $1,31,90,163$ metric tons. In the
Financial Year 2015-16, the average yield rate of Aman rice has been estimated 2.412 metric tons per hectare which is $1.13 \%$ higher than that of last year (BBS, 2016).

When rainfall is normally low, Bangladesh experiences a dry period for several months in every year. However, in the pre-monsoon (March-May) and post-monsoon (OctoberNovember) periods, drought mostly affects this country. More than $40 \%$ damage to broadcast Aus can be caused due to a strong drought. It causes significant destruction to the transplant aman crop, during the kharif season, in approximately 2.32 million ha every year. In the rabi season, about 1.2 million ha of agricultural land face droughts of different magnitudes (Dey et al., 2011). In Bangladesh, unlike most of the rain-dependent rice varieties planted in the aman monsoon season occurring from 
July to November, BINA dhan7, BRRI dhan56 and BRRI dhan71 remain healthy under drought, which can occur at the end of the season, because these varieties take a shorter time to mature than other popular local varieties.

Optimum age of seedling is an important factor in order to get maximum yield. When seedlings of optimum age are transplanted in the right time, it ensures proper tillering and normal growth of rice plant. Healthy seedlings of optimum age also give better rice yield. It also has an influence on plant height, panicle length, grains per panicle and other yield contributing characters. The general performance of crop is retarded due to the use of over aged seedlings and it also reduces the yield of crop (Bozorgi et al., 2011). Therefore, the present study was undertaken to determine the optimum age of seedlings for drought tolerant, short duration, high yielding T. Aman rice cultivars.

\section{MATERIALS AND METHODS}

\section{Experimental site}

The experiment was carried out at the Field Laboratory of the Department of Agriculture, Noakhali Science and Technology University (NSTU), Sonapur, Noakhali, from the period from July 2017 to December 2017. The experimental field belongs to the agro-ecological zone of the Young Meghna Estuarine Floodplain (AEZ-18). The experiment field was almost level land having sandy loam soil and was moderately alkaline. The soils become saline in dry season.

\section{Experimental treatments and design}

The experiment consisted of three varieties viz. BINA dhan7, BRRI dhan56 and BRRI dhan71 and five different ages of seedling viz. 15 days old, 20 days old, 25 days old, 30 days old, 35 days old. The experimental design was randomized complete block design (RCBD) with three replications. The size of the unit plot was $4.0 \mathrm{~m} \times 2.5 \mathrm{~m}$, having an area of $10 \mathrm{~m}^{2}$. Fifteen treatment combinations were randomly assigned in each replication. Thus the total number of unit plot was 45 . A spacing of $1.0 \mathrm{~m}$ and $0.5 \mathrm{~m}$ was maintained in between the replications and unit plot, respectively.

\section{Experimental and field conditions}

The collected seeds were soaked in the water for 24 hours. Then they were taken out of water, covered with wet gunny bags and kept for sprouting. After 48 hours the seeds were started sprouting and after 72 hours almost all seeds were sprouted. At the Field Laboratory of Department of Agriculture, NSTU, Noakhali, seedlings were raised in a well prepared nursery bed. A power tiller was used to open the experimental land. Later on, the land was prepared by ploughing and cross-ploughing and subsequently leveled by laddering. All weeds and stubble were removed from the land by hand. The field was fertilized with urea, triple super phosphate (TSP), muriate of potash (MoP), gypsum and zinc sulphate at the rate of 180, 100, 60, 70 and 8 $\mathrm{kg} \mathrm{ha}^{-1}$ respectively. The uprooting of seedlings was done carefully from the nursery bed. The nursery bed was slightly irrigated before uprooting the seedlings for easier uprooting. Uprooted seedlings were transplanted in the unit plots on $29^{\text {th }}$ July ( 15 days old), $3^{\text {rd }}$ August ( 20 days old), $8^{\text {th }}$ August ( 25 days old), $13^{\text {th }}$ August ( 30 days old) and $18^{\text {th }}$ August (35 days old) 2017 respectively maintaining spacing of $25 \mathrm{~cm} \times 15 \mathrm{~cm}$ (Row to row and Plant to plant) at the rate of 2-3 seedlings per hill. Weeding and gap filling was done as a part of intercultural operations in order to ensure and maintain the normal growth of the crop.

\section{Data collection and analysis}

The crop was harvested at full maturity. The date of harvesting was confirmed when $90 \%$ of the grain became golden yellow in color. For recording data, five hills (excluding border hills) were selected randomly from each unit plot. The harvested crop was threshed by pedal thrasher. Grains were then sun dried at $14 \%$ moisture level and cleaned. Straws were also sun dried properly. Finally straw and grain yield per plot were recorded and converted to ton per hectare. Data recorded for yield and yield contributing characters were compiled and tabulated in proper form for statistical analyses. MSTAT-C computer package programme developed by Russel (1986) was used to analyze the variance. Among the treatments, the mean differences were adjudged by DMRT test (Gomez and Gomez, 1984a, b).

\section{RESULTS AND DISCUSSION}

Effect of variety on yield and yield components of drought tolerant transplant aman rice

The effect of variety on yield and yield contributing characters of drought tolerant transplant aman rice has been presented in Table 1. The plant height was significantly influenced by varieties. The tallest plant $(124.9 \mathrm{~cm})$ was obtained from BRRI dhan71 and the shortest $(105.0 \mathrm{~cm})$ one was from BINA dhan7. Zubaer et al. (2007) and Uddin et al. (2010) also found variation in plant height due to the effect of varieties. This variation in plant height is probably due to the genetically make-up of the varieties. Number of total tillers hill $^{-1}$ was significantly influenced by varieties. The highest number of total tillers hill ${ }^{-1}$ (13.79) was found in BINA dhan7 and the lowest number (10.04) was found in BRRI dhan71. Wu et al. (1998) noticed that total tillers hill ${ }^{-1}$ differed significantly among the varieties in Aman season. Number of effective tillers hill ${ }^{-1}$ was significantly influenced by varieties. The highest number of effective tillers hill $^{-1}$ (13.33) was found in BINA dhan7 and the lowest number (9.787) was observed in BRRI dhan71. Number of non-effective tillers hill ${ }^{-1}$ was non-significantly influenced by varieties. The highest number of non-effective tillers hill ${ }^{-1}(0.8200)$ was found in BRRI dhan 56 and the lowest number $(0.700)$ was observed in BINA dhan7. Significant differences in number of tillers hill $^{-1}$ in 17 rice varieties were found by Mondal et al. (2005). Differences in the production of total tillers and effective tillers hill $^{-1}$ might be due to genetic variation, physiological functions and growth characters of the cultivars under study (Islam et al., 2017). The panicle length was significantly influenced by variety. The 
longest panicle $(27.02 \mathrm{~cm}$ ) was found in BRRI dhan71 and the shortest (25.58) was in BRRI dhan56. The number of grains panicle $^{-1}$ was significantly affected by varieties. The highest (163.3) number of grains panicle ${ }^{-1}$ was obtained by BRRI dhan56 and the lowest (120.9) number of grains per panicle was recorded by BINA dhan7. Variety had significant effect on number of sterile spikelet panicle ${ }^{-1}$. The highest (34.45) was recorded from BRRI dhan71 and the lowest number of sterile spikelet panicle ${ }^{-1}$ (21.28) was produced by BINA dhan7. Chowdhury et al. (1993) reported differences in number of sterile spikelets panicle ${ }^{-1}$ due to varietal differences.

Thousand grains weights is an important character which determines the yield per hectare. There was significant variation in number of 1000 -grains weight. The highest 1000 -grains weight $(23.73 \mathrm{~g})$ was recorded from BRRI dhan71 and the lowest (22.68 g) was recorded from BINA dhan7. Grain yield varied significantly among the varieties. BRRI dhan71 produced the highest grain yield $\left(5.567 \mathrm{t} \mathrm{ha}^{-1}\right)$. The lowest grain yield (4.975 t ha $^{-1}$ ) was obtained from BRRI dhan56. Islam et al. (2017) also found significant variations in grain yield among the cultivars due to the effect of varieties. The variety had no significant effect on straw yield. The maximum straw yield (6.14 $\mathrm{t} \mathrm{ha}{ }^{1}$ ) was obtained from BRRI dhan71 and the lowest straw yield (5.703 $\mathrm{t} \mathrm{ha}^{-1}$ ) was obtained from BINA dhan7. There was no significant variation among the varieties on harvest index. The highest harvest index (48.38\%) was obtained from BINA dhan7 and the lowest highest harvest (45.71\%) was from BRRI dhan 56 .

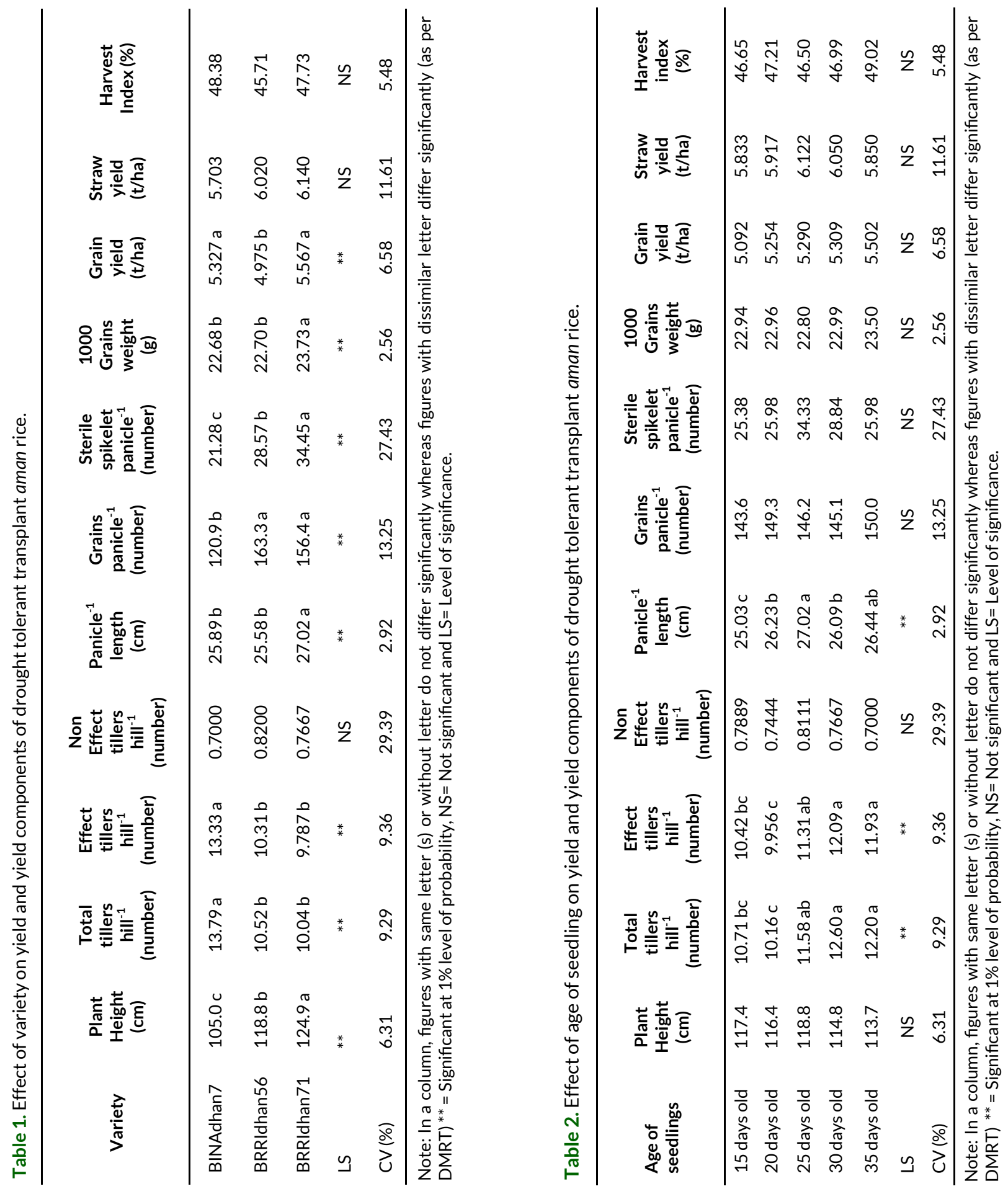


Effect of age of seedling on yield and yield components of drought tolerant transplant aman rice

The effect of age of seedling on yield and yield components of drought tolerant transplant aman rice has been presented in Table 2. The plant height was not significantly influenced by the age of seedling of transplanting. Plant height was highest $(118.8 \mathrm{~cm})$ in case of 25 days age of seedling of transplanting and lowest $(113.7 \mathrm{~cm})$ in case of 35 days old. This might be due to the fact that optimum age of seedling of transplanting (which in this case was 25 days aged seedling) helped crop to complete its vegetative phase in favorable climatic condition. The number of total tillers hill ${ }^{-1}$ was significantly influenced by the age of seedling of transplanting. The number of total tillers hill ${ }^{-1}$ was highest (12.60) in case of 30 days age of seedling of transplanting and the lowest number (10.16) was found in case of 20 days age of seedling of transplanting. The result showed that relatively older seedlings produce more tiller than younger seedlings. Number of effective tillers hill ${ }^{-1}$ was significantly influenced by the age of seedling of transplanting. It was observed that the highest number of effective tillers hill ${ }^{-1}(12.09)$ was found when 30 days old seedlings are transplanted and the lowest number of effective tillers hill ${ }^{-1}$ (9.956) was produced when 20 days old seedlings were transplanted. Sarker et al. (2012) also found significant influence in total tillers hill ${ }^{-1}$ and effective tillers hill ${ }^{-1}$ due to the effect of age of seedling. Number of non-effective tillers hill ${ }^{-1}$ was not significantly influenced by the age of seedling of transplanting. It was observed that the highest number of non-effective tillers hill ${ }^{-1}(0.8111)$ was found when 25 days old seedlings were transplanted and the lowest number of non-effective tillers hill ${ }^{-1}(0.7000)$ was found when 35 days old seedlings were transplanted. The length of panicle was significantly influenced by age of seedling of transplanting. It was observed that the longest panicle (27.02) was found when 25 days old seedlings were transplanted and the shortest panicle (25.03) was found when 15 days old seedlings were transplanted. Sarker et al. (2012) reported that panicle length varied significantly due to the effect of age of seedling. The number of grains panicle ${ }^{-1}$ was not significantly affected by the age of seedling of transplanting. The highest number of grains panicle ${ }^{-1}$ (150.0) was obtained when 35 days old seedlings were transplanted and the lowest (143.6) was from 15 days old. Age of seedling had no significant effect on number of sterile spikelets panicle ${ }^{-1}$. The highest number of sterile spikelets panicle ${ }^{-1}$ (34.33) was recorded in case of 25 days old seedling of transplanting and the lowest (25.38) was recorded in case of 15 days old seedling of transplanting. Weight of thousand grains was not significant influenced by the age of seedling. The highest 1000 -grains weight $(23.50 \mathrm{~g})$ was recorded on 35 days old and the lowest1000-grains weight $(22.94 \mathrm{~g})$ was recorded on 15 days old. Mobasser et al. (2007) reported that seedlings age had no significant effect on grains panicle ${ }^{-1}$, sterile spikelets panicle $^{-1}$ and 1000-grains weight. Grain yield was not significantly affected by different ages of seedlings. The highest grain yield $\left(5.502 \mathrm{t} \mathrm{ha}^{-1}\right)$ was recorded when 35 days old seedlings were transplanted and the second highest grain yield $\left(5.309 \mathrm{t} \mathrm{ha}^{-1}\right)$ was recorded on 30 days old. The lowest grain yield $\left(5.092 \mathrm{t} \mathrm{ha}^{-1}\right)$ was obtained when 15 days old seedlings were transplanted. Shahani et al. (1983), Chandra and Manna (1988), Ali and Rahman (1992) and Paul (1994) stated that age of seedlings had no significant effect on grain yield. Straw yield was not significantly affected by the age of seedlings. The highest straw yield $\left(6.122 \mathrm{t} \mathrm{ha}^{-1}\right)$ was recorded from 25 days old seedlings of transplanting and the lowest $\left(5.833 \mathrm{t} \mathrm{ha}^{1}\right)$ was obtained from 15 days old seedlings of transplanting. Age of seedlings had no significant effect on harvest index. The highest harvest index (49.02\%) was from 35 days old seedling of transplanting and the lowest harvest index (46.50\%) was from 25 days old seedling of transplanting.

Interaction effect of variety and age of seedlings on yield and yield components of drought tolerant transplant aman rice The interaction effect of variety and age of seedlings on yield and yield contributing components of drought tolerant transplant aman rice has been presented in Table 3. Plant height was not significantly affected by the interaction between variety and age of seedling of transplanting. The tallest plant $(127.3 \mathrm{~cm})$ was observed from BRRI dhan71 both at 20 days old and 25 days old and the shortest $(101.9 \mathrm{~cm})$ plant height was observed from BINA dhan7 at 35 days old seedlings of transplanting. Number of total tillers hill ${ }^{-1}$ was not significantly affected by the interaction between variety and age of seedling of transplanting. Highest number of total tillers hill ${ }^{-1}(15.20)$ was observed in BINA dhan7 at 35 days of age of seedling of transplanting and the lowest number (8.800) was observed in BRRI dhan71 at 20 days old. Number of effective tillers hill ${ }^{-1}$ was not significantly affected by the interaction between variety and age of seedling of transplanting. Highest number of effective tillers hill ${ }^{-1}$ (14.80) was observed in BINA dhan7 when 35 days old seedlings were transplanted and the lowest number (8.733) was observed in BRRI dhan 71 when 20 days old seedlings were transplanted. Number of non-effective tillers hill ${ }^{-1}$ was notsignificantly affected by the interaction between variety and age of seedling of transplanting. Highest number of noneffective tillers hill ${ }^{-1}(1.000)$ was observed in BRRI dhan 56 when 35 days old seedlings were transplanted and the lowest number (0.4333) was observed in BINA dhan7 when 35 days old seedlings were transplanted. The length of panicle was not significantly influenced by the interaction between variety and age of seedling of transplanting. It was observed that the longest panicle $(28.17 \mathrm{~cm})$ was found in BRRI dhan71 when 25 days old seedlings were transplanted and the lowest number $(24.67 \mathrm{~cm})$ was observed in BRRI dhan 56 when 20 days old seedlings were transplanted. Non-significant variation was observed in number of filled grains per panicle due to interactional effect. The highest (174.7) number of grains per panicle was recorded in BRRI dhan56 with 35 days old seedlings and the lowest (108.3) was recorded in BINA dhan7 with 35 days old seedlings. There was no significant variation in the number of sterile spikelets panicle ${ }^{-1}$ due to the interactional effect. The highest number of sterile spikelets panicle ${ }^{-1}$ (43.13) was recorded in BRRI 
dhan71 with 25 days old and the lowest number of sterile spikelets panicle $^{-1}$ (17.07) was found in BINA dhan7 with 35 days old seedlings of transplanting. 1000-grains weight was not significantly influenced by the interaction of variety and age of seedlings. The highest (24.22 g) 1000-grains weight was recorded in BINA dhan7 with 35 days old and lowest (22.0 g) was recorded in BINA dhan7 with 20 days old seedlings of transplanting. The grain yield was not significantly influenced by the interaction of variety and age of seedlings. The highest grain yield $\left(5.723 \mathrm{t} \mathrm{ha}^{-1}\right)$ was obtained from BRRI dhan71 with 35 days old and the lowest (4.730 t ha $\left.{ }^{-1}\right)$ was obtained from BRRI dhan56 with 15 days old seedlings of transplanting. Effect of interaction of variety and age of seedlings on straw yield was not significant. The highest straw yield $16.750 \mathrm{t}$ $\mathrm{ha}^{-1}$ ) was recorded in BRRI dhan71 with 25 days old and the lowest (5.167 $\mathrm{t} \mathrm{ha}^{-1}$ ) was found in BRRI dhan56 with 25 days old seedlings of transplanting. Harvest index was not significantly influenced by the interaction between variety and age of seedling. The highest harvest index (52.10\%) was obtained from BRRI dhan71 with 35 days old and the lowest (44.07\%) was obtained from BRRI dhan 56 with 15 days old seedlings of transplanting.

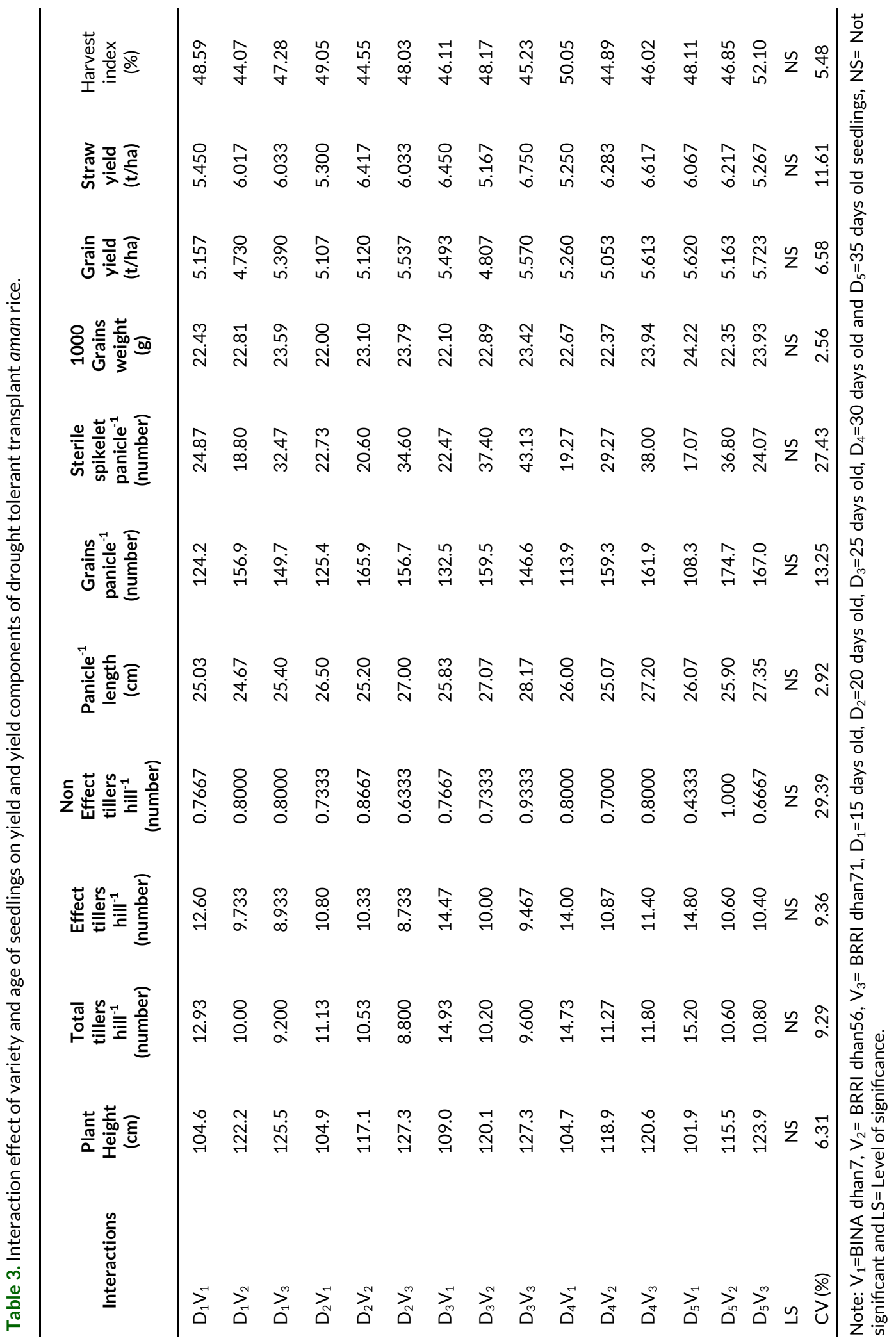


Conclusion

The result indicated that most of the yield and yield contributing characters of drought-tolerant transplant Aman rice cultivars performed better when relatively older ( 35 days old) seedlings were transplanted. BRRI dhan71 with 35 days old seedlings produced the highest grain yield of $5.725 \mathrm{t} \mathrm{ha}^{-1}$ which was statistically identical to all other combinations used for this experiment including BINA dhan7 with 35 days old seedlings ( 5.620 t ha $^{-1}$ ) and BRRI dhan71 with 30 days old seedlings (5.613 $\mathrm{t} \mathrm{ha}^{-1}$ ). But, BRRI dhan71 with 35 days old seedlings performed well in the field throughout the whole growing period. Therefore, it can be concluded that 35 days old seedlings of BRRI dhan 71 are the better choice to get maximum grain yield.

\section{ACKNOWLEDGEMENTS}

The authors are thankful to the Department of Agriculture, Noakhali Science and Technology University (NSTU) for partially financing the experiment.

Open Access: This is an open access article distributed under the terms of the Creative Commons Attribution 4.0 License, which permits unrestricted use, distribution, and reproduction in any medium, provided the original author(s) if the sources are credited.

\section{REFERENCES}

Ali, M.Y. and Rahman, M.M. (1992). Effect of seedling age and transplanting time on late planted Aman rice. Bangladesh Journal of Training and Development, 5: 75-83

BBS (Bangladesh Bureau of Statistics). (2016). Yearbook of Agricultural Statistics. Bangladesh Bureau of Statistics, Statistics and Informatics Division (SID), Ministry of Planning, Government of the People's Republic of Bangladesh. pp. 49-77.

Bozorgi, H.R., Faraji, A., Danesh, R.K., Keshovarz, A., Azarpour, E. and Tarighi, F. (2011). Effect of plant density on yield and yield components of rice. World Applied Sciences Journal, 12 (11): 2053-2057.

Chandra, D. and Manna, G.B. (1988). Effect of planting date, seedling age and planting density on late planted wet season rice. International Rice Research News Letter, 13: 3031.

Chowdhury M.J.U., Majib A.U., Sarkar M.S.R. and Kashem M.A. (1993). Effect of variety and number of seedlings $m-2$ on yield and its component on late T. aman rice. Bangladesh Journal of Agricultural Research, 20(2): 311-316.

Dey, N.C., Alam, M.S., Sajjan, A.K., Bhuiyan, M.A., Ghose, L., Ibaraki, L. and Karim, F. (2011). Assessing Environmental and Health Impact of Drought in the Northwest Bangladesh, Journal of Environmental Science and Natural Resources, 4(2): 89-97, https://doi.org/10.3329/jesnr.v4i2.10141

FAO (1995). Food and Agriculture Organization, Production Year Book of 2010. No. 62. FAO, Rome, Italy. pp. 54-55.

Gomez, K.A. and Gomez, A.A. (1984a). Ducan's Multiple Range Test. Statistical Procedures for Agricultural Research. 2nd Edition, A Wiley Inter-Science Publication, Jhon Wiley and Sons, New York. pp. 202-215.

Gomez, K.A. and Gomez, A.A. (1984b). Statistical Procedure for Agricultural Research. 2nd ed. John Wiley and Sons. New York. pp. 64.

Islam, T. and Salam, M.A. (2017). Effect of number of seedlings hill-1 on the yield and yield contributing characters of short duration Aman rice cultivars. Progressive Agriculture 28(4): 279-286, https://doi.org/10.3329/pa.v28i4.36367

Mobasser, H.R., Tari, D.V., Vojdani, M., Abadi, R.S. and Eftekhari, A. (2007). Effect of seedling age and planting space on yield and yield components of rice (Neda Variety). Asian Journal of Plant Science 6(2): 438-440, http://doi.org/10.3923/ ajps.2007.438.440

Mondal M.M.A., Islam A.F.M. and Siddique M.A. (2005). Performance of 17 modern transplant aman rice cultivars in the northern region of Bangladesh. Bangladesh Journal of Agricultural Research, 16: 23-29.

Paul, S.R. (1994). Effect of age of seedling and dates of planting on grain yield of saline rice in Assam. Annals of Agricultural Research, 15: 126-128.

Russel, D.F. (1986). MSTAT-C package programme. Crop and Soil Sci. Dept., Michigan State Univ., USA, pp. 103-112.

Sarker, T.K., Hossain, M.D., Salam, M.A. and Rabbani, M.G. (2012). Effect of seedling age and method of transplanting on the yield of aman rice. Progressive Agriculture, 24(1\&2): 916, https://doi.org/10.3329/pa.v24i1-2.19092

Shahani, B.H., Khan, A.B. and Khan, M.A. (1983). Effect of seedling age at transplanting and fertilizer levels on grain yield. International Rice Research News Letter, 9: 27

Uddin, M.J., Hasan, M.M., Ahmed, S. and Hasan, M.M. (2010). Effect of spacing on morpho physiological response of different T. aman rice cultivars under coastal high land ecosystem. Indian Journal of Agricultural Research. 44: 251258.

Wu, G., Wilson, L.T. and McClung, A.M. (1998). Contribution of rice tillers to dry matter accumulation and yield. Agronomy Journal 90 (3): 317-323. https://doi.org/10.2134/ agronj1998.00021962009000030001x

Zubaer, M.A., Chowdhury, A.K.M.M.B., Islam, M.Z., Ahmed, T. and Hasan M.A. (2007). Effects of water stress on growth and yield attributes of aman rice genotypes. International Journal of Sustainable Crop Production, 2: 25-30. 